\title{
参道空間における空間構成要素の誘引効果に関する研究 THE ATTRACTION OF ELEMENTS ON APPROACH SPACES TO BUDDHIST TEMPLES
}

\author{
山口 満*, 長 善 規**, 伊藤 嘉 記*** \\ Mitsuru YAMAGUCHI, Yoshinori CHO and Yoshinori ITO
}

\begin{abstract}
The sequence of approach spaces to Buddhist temples was studied, from the point of leading peoples to. Attractions of 51 photographs, representing elements (entrance, stone pavement, stone steps, gate, main hall, bridge, bend), taken in 6 temples approach spaces in Nagano prefecture liyama city, were evaluated in 7 stages by 35 peoples.

As results, 1:Attractions of entrance, stone pavement, stone steps and bridge were different in go and back. 2:Attractions were changing stronger gradually according to the approaching the main hall. 3:The space attraction between the gate and the main hall was developed by the existence of the gate.
\end{abstract}

Keywords : Buddhist temple, approach space, sequence, element, attraction, evaluation 寺院, 参道, シークエンス, 構成要素, 誘引, 評価

1.はじめに

本研究は既往研究注 1)の続編である。前編では, 次の 2 点を背景に, 寺町のイメージを探っている。

(1)1994 年度から全国 7 都市（飯山市・大野市・金沢市・岐阜市・ 上越市・高岡市・松江市）によって毎年開催されている寺町サミ ットで「寺院を生がしたまちづくり」を統ーテーマとして街づく りの模索が行われていること。

(2) ヨーロッパの例を考えてみると, 例えばカミロ・ジッテの著書 「広場の造形」注2〕において教会の位置が広場の分析においてきわ めて重要であること。

本編においては, 同様な背景の基に, 街と寺院との空間的連続性 の特徵を考察しようとするものである。

長野県飯山市は, 21 寺院により寺院群が形成されていることによ り「寺町」と呼ばれている地区である。しかし, 寺院は, 日常生活 が営まれている生活空間にとけ込むように存在しているのではな く, 参道という連結空間を介して生活空間と具体的に連続している。 このような接続空間としての参道空間は，一端を街に接続し，各所 に空間構成要素が設けられることによって連続的に中心的施設に 近づいていく空間と捉えることができる。つまり，参道空間は，入 ロ・石睤・山門・石段といった空間構成要素によって参詣者に対し
てなんらかの認知的変化をもたらしつつ街から境内一と連続して いる空間であり, 参詣者を寺院へ誘導するという観点から街と寺院 との空間的連続性が捉えられると考えられる空間である。

また, 寺院や参道空間という歴史的に洗練されてきた空間から現 代でも通用している様々な空間的特徵を読みとり, 今後の都市空間 計画への応用を模索していくことは意義梁いことであると考えら れる。特に, 地方都市における地域に固有な都市空閒を分析する場 合には, 参道空間による寺院と街との空間的関係性の分析は, 今後 の重要な切り口のひとつになると考えられる。

そこで, 本研究では, 参道空間を建築的シークエンスを有するア プローチ空間として捉え, 参詣者を寺院へ誘導する効果を「誘引効 果」と定義し, 参道空間の誘引効果の状況を把握寸るとともに, 誘 引効果と空間構成要素との関係性を把握することを目的としてい る。

\section{2. 既往研究からの位置付け}

これまでの同市における寺町を扱った研究としては，山口・山崎 の研究注1)があげられる。この研究は, 長野県飯山市における「寺町」 についての人々のイメージを分析することによって, 街のイメージ に対する寺の影響を把握したものである。しかし，「寺町」という

\footnotetext{
* 信州大学工学部社会開発—学科建築コース

講師 - 博士 (工学)

*** (制中央住宅 修士 (工学)

***フリー 修上(工学)
}

Lecturer, Dept. of Architecture, Faculty of Eng., Shinshu Univ., Dr. Eng.

Chuo Jutaku Co., Ltd., M. Eng.

Free, M. Eng. 
研究対象には常に寺院が背景に存在するのであるが，この研究では 寺院の影響を受けた街のみを研究対象としており, 寺院や参道空間 の空間構造には触れていない。そこで, 本研究では, 街からの連続 性という観点から寺院の参道空間に着目し, 考察を行っている。

また，本研究では参道空間をアプローチ空間と捉えているのであ るが, アプローチ空間を扱っている研究としては, 鈴木・志水・山 口・杉本の研究社3)がある。この研究では，6つのアプローチ空間に おける「折れ曲がり」，「くぐりぬけ」といった行為について，「跳 ぶ記憶」という概念を用いて, 被験者の認知構造を探っている。こ の研究は，歩行体験の中での人間の認知構造を学習という観点から 探ることを目的としているのであるが，アプローチ空間における空 間構成要素に対する詳細な分析は行われていない。

参道空間を認知的側面から扱った先駆的研究として, 船越・積 田・清水の研究注 4) がある。この研究は, 神社の参道空間を対象に分 節点の位置 · 分節点の構成要素・分節点の物理量の分析が行われた ものであり，参道空間の空間構造を詳細に把握している。その他に， 船越・積田らは街路空間に対しても同様な分析を行い, さらに心理 量・ゆらぎに関して分析を進め, シークエンシャルな空間構造の詳 細な研究が進められている注5)。本研究は, これらの研究による知見 の多くを参考とするものであるが, 誘引効果という単一の心理量か ら参道区間のシークエンシャルな空間構造を捉えている点におい て異なっている。

その他に，寺町を対象にしている研究としては，千葉・戸沼らの 研究注 ${ }^{6}$ がある。これらの研究では, 居住環境整備における寺院利用 の可能性, 対象地区内の寺町としての環境整備の必要性, 寺院移 転・集積の変容, 墓地政策の変容と現状, 行政的土地管理状況, な どを把握することを目的としており, 寺町の構成要素である寺院に 主眼をおき，寺院による寺町の在り方について詳細に研究されてい る。しかし，参道空間による街と寺院との空間的連続性に関しては 研究されていない。

なお，参道空間を対象とした既往研究では，参道の帰り道につい ての考察は行われていないが, 本研究では, 参詣者の帰路における 空間構成要素の影響も考察の対象としている。

\section{3. 誘引評価実験の概要}

参詣者を寺院へ誘導するという観点から街と寺院との空間的連

表 3 主要な「誘い込まれる」理由(上位 5 件)

\begin{tabular}{|c|c|c|c|}
\hline 諉い込まれる理由；往路 & 件数 & 唀い込まれる理由；復路 & 件数 \\
\hline 先に何があるか気になるから & 44 & 先に何があるのか気になるから & 38 \\
\hline 石段によって & 42 & 石眰によって & 32 \\
\hline 石量によって & 37 & 山門によって & 27 \\
\hline 山門によって & 27 & 庭がきれいだから & 23 \\
\hline 山門からのぞく本堂によって & 24 & 紅莱がきれいだから & 11 \\
\hline
\end{tabular}

表 4 主要な「誘い込まれない小理由(上位 5 件)

\begin{tabular}{|c|c|c|c|}
\hline 誘い込まれない理由；往路 & 件数 & 誘い込まれない理由；復路 & 件数 \\
\hline 全体像が自えてしまっているから & 20 & 道路へ出てしまうから & 52 \\
\hline 民家はかかりだから & 17 & 民家ばかりだから & 46 \\
\hline 道路によって & 15 & 面白い空問がなさそうだから & 21 \\
\hline 寺院がよくなさそうだから & 10 & 寺から出て行く印象を受けるから & 18 \\
\hline 菓が邪魔だから & 10 & 電柱と家など人工物によって & 13 \\
\hline
\end{tabular}

表 1 実験対象寺院の概要
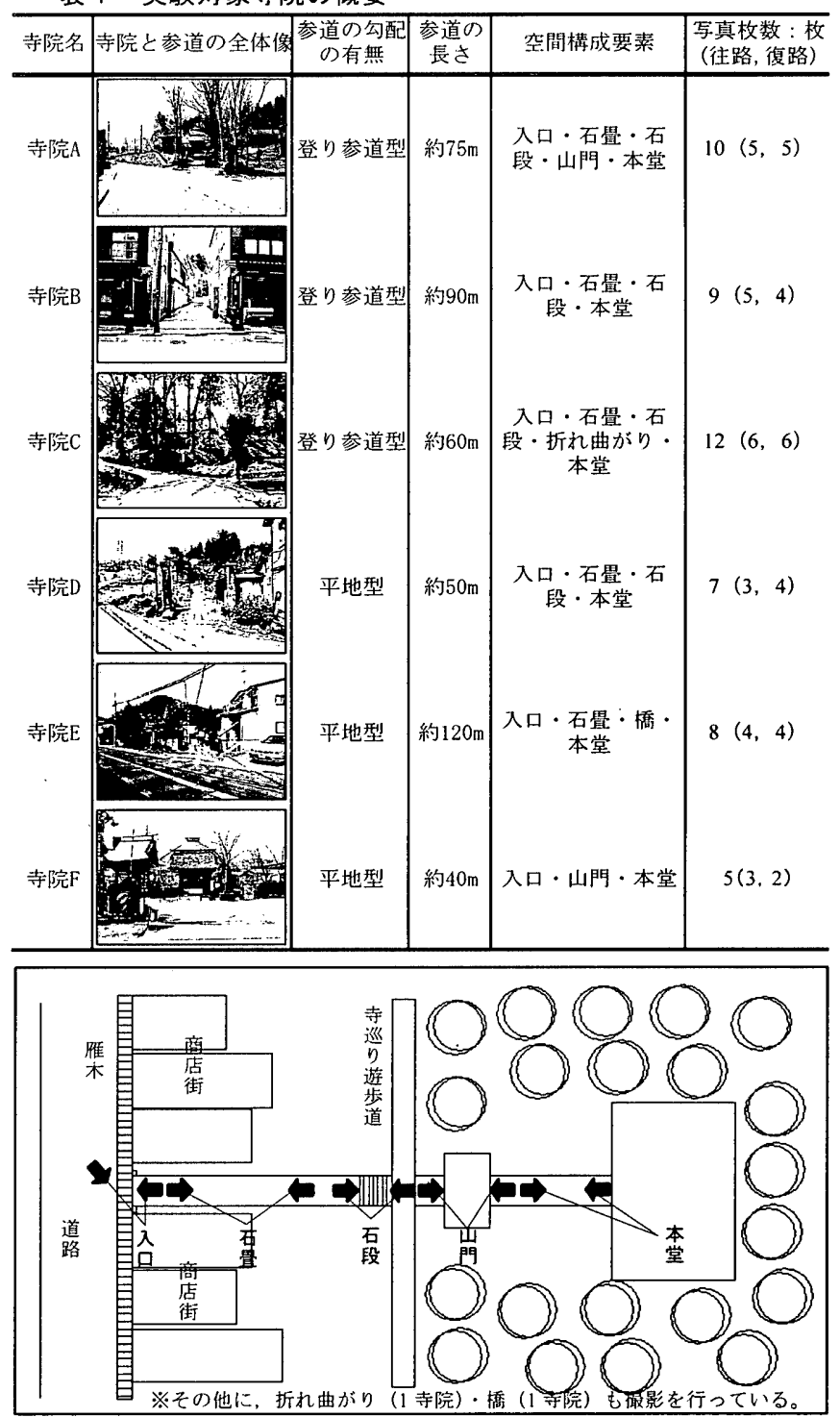

図 1 実験用サンプル撮影の概要（注 矢印は影影場所，方向を示す。）

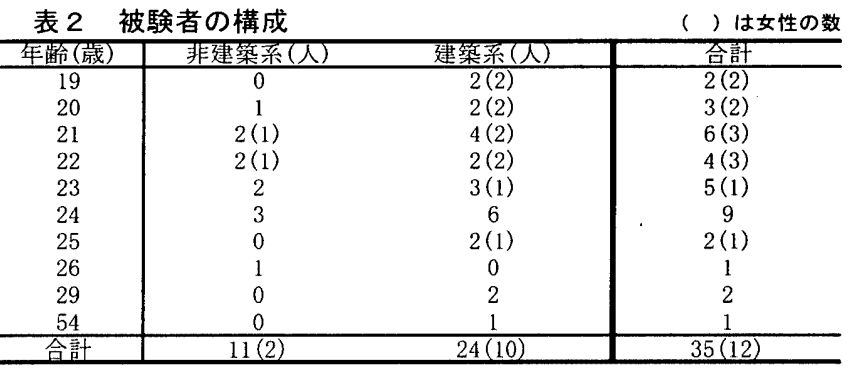

質問1. 寺院の参道の写真をお見せします。

写真を見ながら、「誘い込まれる」度合を7段階で評洒してください。

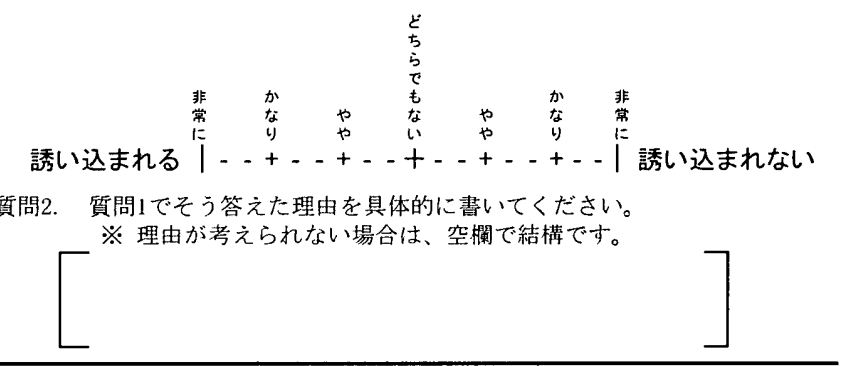

図 2 質問用紙 


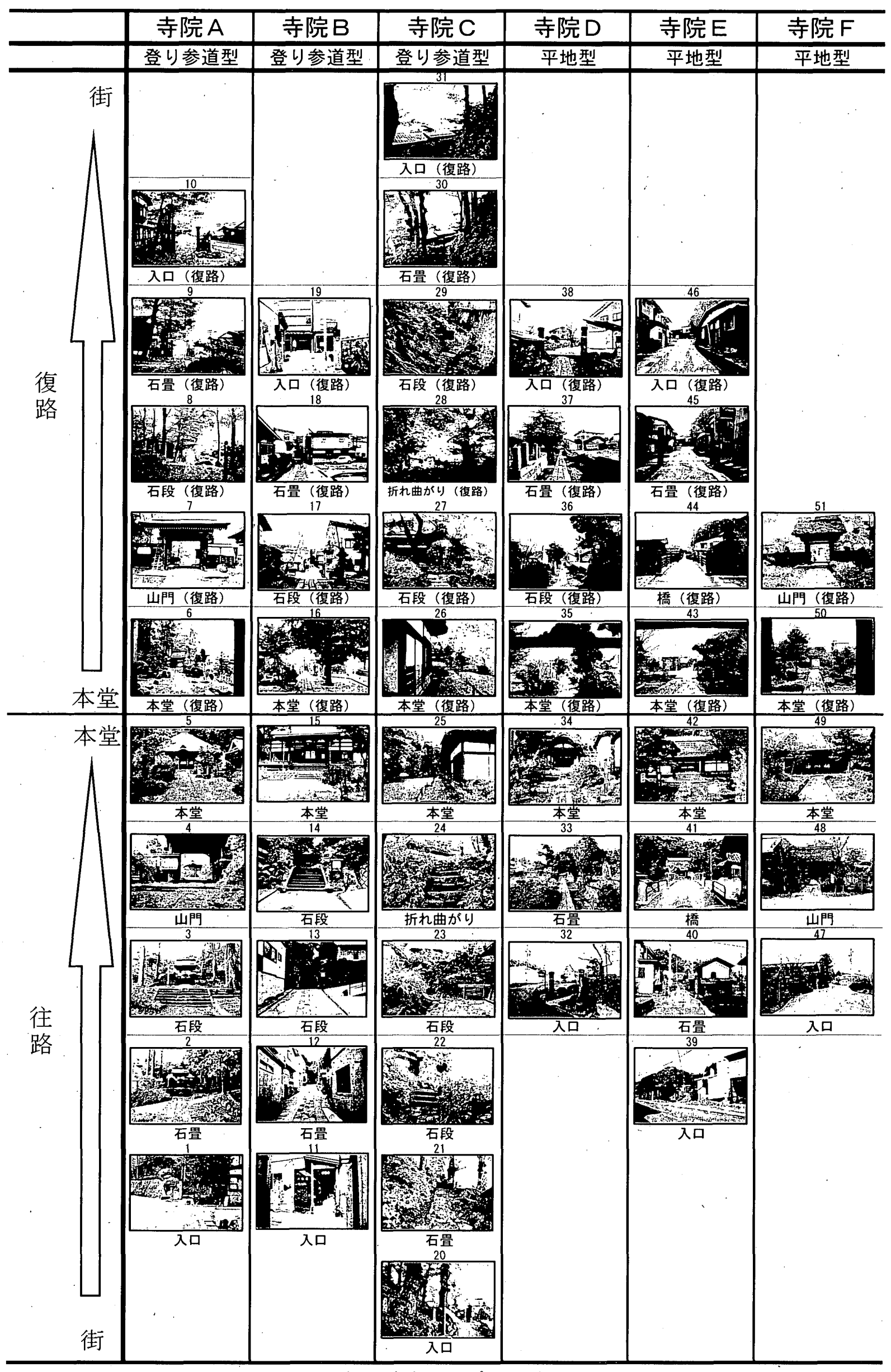

写真 1 実験用サンプル（51 枚） 
続性を捉えるために，参道空間構成要素の誘引評価実験を行った。

実験対象の参道空間は, 長野県飯山市の 21 寺院の中から, 参道 の勾配の有無（登り参道型・平地型）および空間構成要素（入口・ 石畳・石段・山門・本堂・橋・折れ曲がり)について分類を行い， 同様な参道空間を一つの参道空間に代表させることによって取捨 選択した，6 寺院の参道空間とした（表 1 )。そして，各参道空間に おける 7 つの空間構成要素（入口・石畳・石段・山門・本堂・橋 折れ曲がり）を本堂に向かう方向（往路）と帰り道の方向（復路） から 2 枚ずっ写真撮影した（図 1)。その中から，石段から撮った 写真が本堂を含む場合は，石段・本堂を 1 枚の写真で代用し，合計 51 枚の写真を実験用サンプルとした（写真 1 )。

実験に用いる写真の撮影については, 撮影する前に現地を複数回 訪れ，次のような検討を行って各構成要素の撮影地点を決定した。

「入口・石段 (往路) ・山門・本堂 (往路) ・橋・折れ曲がり」 については，実際に寺院に参詣に来たつもりで各構成要素を目 にする場合と違和感がないことを確認し, その結果, 各構成要 素の面積が全画面の $1 / 4$ 程度になる地点から撮影した。

「石畳」については, 連続している長さが捉えられる必要があ るため, 画面中央のパース消点位置に見えるその他の構成要素 が石冨と比較して無視できる小ささになる地点, すなわち, 画 面の下端から画面中央までの三角形の範囲を石畳が占めるよ うになる地点から撮影した。

「石段（復路）」については，石段そのものは見えないので， 石段の最上段が参道において違和感無く画面に納められるこ とを確認し，その結果，画面の下から $1 / 4$ 程度に石段の最上段 が位置する地点から撮影した。

「本堂 (復路)」については，本堂そのものは見えないので， 一般に立ち入れる最も奧の地点（本堂軒下も含む）から撮影し た。

撮影には $28 \mathrm{~mm}$ P Cレンズを用いて目の高さ（約 $150 \mathrm{~cm} ）$ から参 道空間の連続方向に向かって撮影を行った。

撮影時の天候は量天とし，2002 年 10 月 27 日〜11月 2 日の 10 時 〜 15 時に撮影を行った。被験者は, 非建築系被験者 11 人, 建築系 被験者 24 人の, 合計 35 人とした（表 2 )。被験者の属性には偏り があるが，参道空間の誘引効果という観点での研究は始めたばかり であり，データの蓄積，安定性を高めるために被験者数を増やすこ とを優先し実験を進めた注7)。

被験者への写真提示順序は, 同寺院内の連続性による影響を排除 するためにランダムとし，各被験者に51 枚の写真それぞれに対し 「非常に誘い込まれる」から「非常に誘い込まれない」までの7段 階で誘引評価を評定させ，同時に誘引評価理由も質問した（図 2 )。 なお，実験では被験者に「寺院に参詣に来たつもりで答えてくださ い。」と伝えた。実験期間は, 2002 年 11 月 8 日〜 12月 22 日であり, 信州大学工学部の研究室内で実験を行った。

\section{4. 参道空間構成要素の誘引効果}

\section{4-1 誘引評価理由による考察}

誘引評価実験で被験者があげた誘引評価理由について，誘い込ま れる理由・誘い込まれない理由, 往路・復路, という観点から誘引
評価理由を考察していく。

誘引評価実験で被験者があげた誘引評価理由の合計は 1289 件で あり，この内，誘い込まれる理由は783 件，誘い込まれない理由は 506 件であった。证8)

主要な誘い込まれる理由を往路・復路別にまとめたものを表 3 , 主要な誘い込まれない理由を同様にまとめたものを表 4 に示す。表 3から誘い込まれる理由は，往路については，「先に何があるか気 になるから」，「石段によって」，「石畳によって」，「山門によって」， 「山門からのぞく本堂によって」の順で多く答えられている。復路 については，「先に何があるか気になるから」，「石畳によって」， 「山門によって」，「庭がきれいだから」、「紅葉がきれいだから」の 順で多く答えられている。往路・復路ともに，「先に何があるか気 になるから」が最も多く答えられている。このことは，現在評価し ている空間構成要素の写真が，その先に続く別の空間や要素を被験 者にイメージさせていることによると考えられる。往路での理由で その他にあげられた理由は，参道上の空間構成要素に関する理由で ある。石段・石畳などに見られる繰り返し連続するパターンによる 誘引効果などが考えられる。往路と復路との誘い込まれる理由を比 較すると，復路には「石段によって」がないことがわかる。このこ とから, 石段は, 参道空間の往路と復路とで誘引効果から捉えた空 間構造に明確な違いを生じさせる構成要素となっていることが示 される。復路でのその他の理由は, 空間構成要素に関する理由以外 に，周辺の樹木などの要素に誘い込まれるという理由も見られた。 主要な誘い込まれない理由（表 4) は, 往路については, 「全体 像が見えてしまっているから」、「民家ばかりだから」,「道路によ って」, 「寺院がよくなさそうだから」,「葉が邪魔だから」の順で多 く答えられている。「全体像が見えてしまっているから」という理 由には，本堂の写真に関する終着点の意識が表れていると考えられ る。復路については, 「道路へ出てしまうから」，「民家ばかりだか ら」,「面白い空間がなさそうだから」,「寺から出て行く印象を受け るから」、「電柱と家など人工物によって」の順で多く答えられてい る。道路・民家・電柱といった街に関倸する空間構成要素が多くあ げられており, 参道空間において街に関係する空間構成要素は, 誘 引効果という観点から寺院に関係する空間構成要素とは対照的に 存在していることが考察される。なお, 往路についても, 入口・石 盼といった参道空間の入口近辺の写真において誘い込まれない理 由として街における空間構成要素があげられている。

\section{4-2 誘引評価値による考察}

誘引評価実験で被験者に評定させた 7 段階の誘引評価値について 考察していく。

実験で得られた評定值について，「非常に誘い込まれる」を評価 値 3，「非常に誘い込まれない」を評価值 - 3 として7 段階の評定值 それぞれを数值化し，写真ごとに被験者の評定值を平均して誘引評 価值を算出した。結果を図 3 に示寸。

この図の左から, 寺院 $\mathrm{A} \sim \mathrm{F}$ の順に誘引評価值が並んでおり, 各 寺院では入口からの参道シークエンスに沿って往路の誘引評価値 が並び, 続いて本堂からのシークエンスに沿って復路の誘引評価値 が並んでいる。すなわち, 図 3 では, 各寺院ごとに往路から復路へ の一連のシークェンスに沿った誘引評価值を見ることができる。 
図 3 から，まず，往路の写真はほとんどが誘引評価值が高いのに 対し, 復路の写真は比較的誘引評価值が低いことがわかる。また, 寺院ごとに見ると，寺院 $\mathrm{A}$ の例に顕著に表れているが，往路におい て入口から徐々に誘引評価值が高くなりピークを迎えて本堂で一 旦評価値が下がり，復路において徐々に誘引評価值が低くなってい くように変化していることがわかる。これは，参道空間に誘引効果 の方向性があり，しかもその強さが本堂に向かって高くなるように 構成されていることを示していると考えられる。つまり，参道空間 の構成要素は，その存在によって，街から寺院空間へ徐々に人々を 誘引するよう構成されていることを示していると考えられる。

次に，復路において誘引評価值の高い場合があることがわかる。 寺院 $\mathrm{A} \cdot \mathrm{C} \cdot \mathrm{F}$ では, 復路においては途中までは誘引評価值が高い。 なお, 寺院 $\mathrm{A} \cdot \mathrm{C} \cdot \mathrm{F}$ には, 空間構成要素として参道の中に山門も しくは折れ曲がりが存在している（表 1 )。

4-3 空間構成要素写真ごとの誘引効果

参道空間構成要素写真ごとの誘い込まれる理由と誘い込まれな い理由との割合を, 往路・復路別に算出し，これらの割合と誘引評 価値との関係について考察していく。図 4 に, 往路・復路別に各構 成要素写真ごとの誘引評価理由の割合を棒グラフで示し, 往路・復 路別各構成要素写真ごとの誘引評価値を線グラフで示す珄9)。

図 4 を見ると，全体的な傾向として，誘い込まれる理由の割合が 高ければ誘引評価值は高く，低ければ誘引評価值は低いことが確認 できる。

次に，前節でも考察されたのであるが，折れ曲がりの写真を除い て, 往路は復路に比べて誘引評価值が高くなっていることがわかる。 誘引評価理由の割合では, 特に, 入口・石畳・石段・橋の写真では, 往路では誘引評価值がプラス側であるとともに誘い込まれる理由 の割合が高く，復路では誘引評価値がマイナス側であるとともに誘 い込まれない理由の割合が高い。よって,これらの要素周辺の空間 は参道空間において方向性別に顕著に異なる誘引効果となるよう 空間が構成されていることが示されている。

また，誘引評価値の推移を見ると，やはり前節でも考察したので あるが，入口・石畳・石段・山門という順序を仮定すると，往路に おいて入口の写真から徐々に誘引評価值が高くなり, 復路において も徐々に誘引評価值が低くなっていくように変化していることが 確かめられる。山門・本堂の写真にういては, 誘引評価值は, 往路・ 復路ともに0を超える。

なお，最も誘引効果が高いと考察できる空間構成要素の写真は山 門である。特に，誘い込まれない理由は 4 件のみであり，最も少な くなっている。

\section{4-4 山門の誘引効果}

4-2で山門もしくは折れ曲がりが存在する寺院 $\mathrm{A} \cdot \mathrm{C} \cdot \mathrm{F}$ では, 復路においては途中までは誘引評価值が高いことが示された。また, 4-3で山門の写真は最も誘引効果が高いことが考察できた。そこ で，山門の有無に注目し，山門の有無別に誘引評価理由と誘引評価 值とを考察する。

山門有り・山門無し別の, 本堂の写真の往路・復路別誘引評価理 由の割合（棒グラフ）と誘引評価値（線グラフ）を図 5 に示す。こ の図を見ると，山門有りの本堂の写真は，往路・復路ともに誘い込

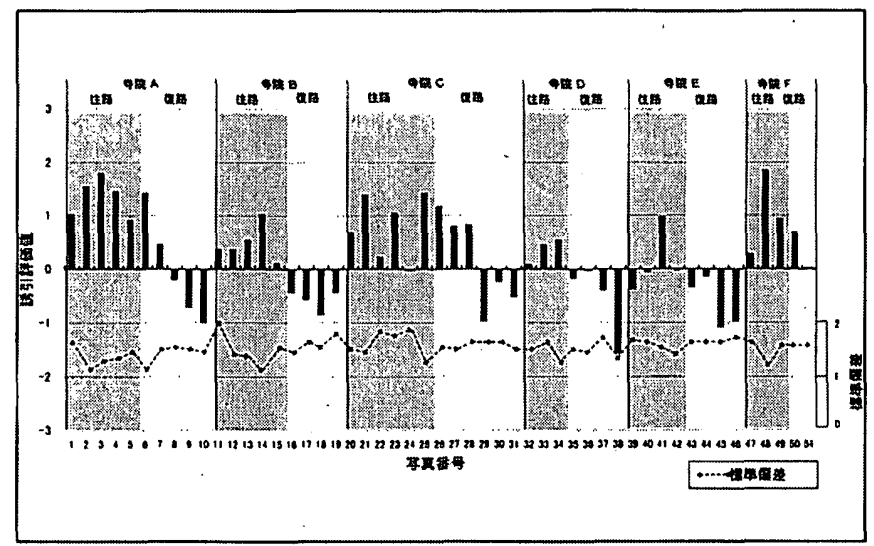

図 3 寺院ごとの誘引評価値シークエンス

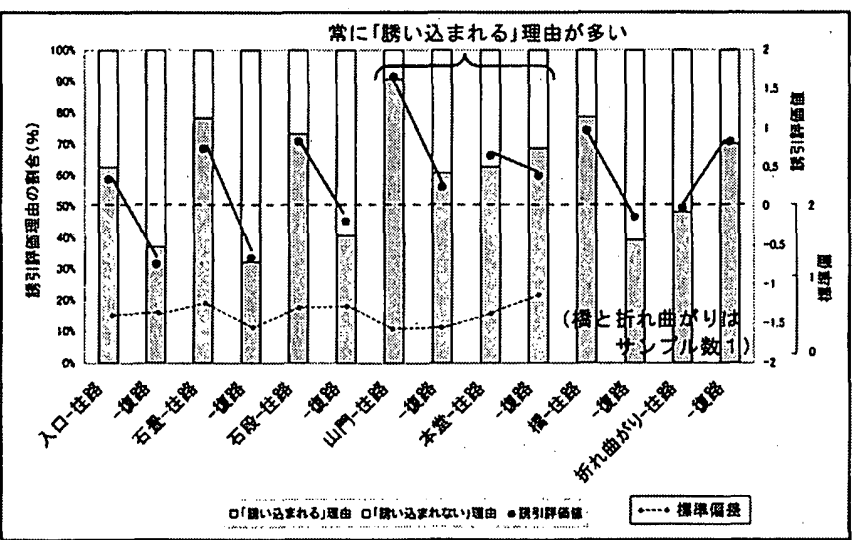

図 4 往路・復路別各構成要素写真の誘引評価値と理由の割合

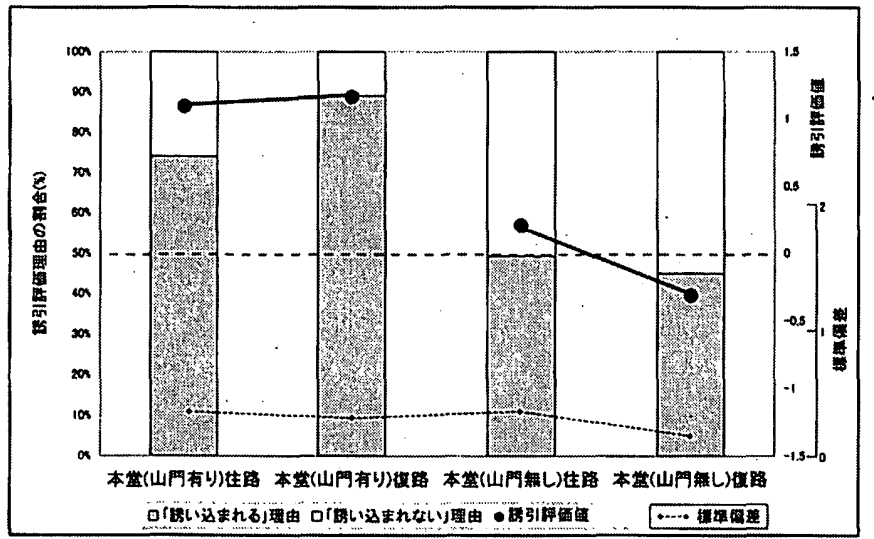

図 5 山門の有無による本堂の写真の誘引評価の違い

まれる理由が圧倒的に多く，山門無しの本堂の写真は，誘い込まれ る理由と誘い込まれない理由がほぼ同率となっている。誘引評価值 に関しても, 山門有りの写真では1を超える值であるのに対し，山 門無しの写真では往路であっても 0 に近く, 復路では 0 未満の值と なっている。また, 特に特徵が表れている復路について誘引評価理 由をまとめたものを表 5 (山門有り)・表 6 （山門無し）に示す。 これらの表を見ると，山門有りの本堂の写真については，誘い込ま れない理由はほとんどあげられず，誘い込まれる理由が圧倒的に多 くあげられている。主な理由としては，「庭がきれい」，「奥が気に なる」，「石畳によって」，「山門によって」がある。山門無しと比心゙ て特徴的な理由は，庭と奥である。復路においてもこのような理由 があげられる原因は，山門によってそこから先の復路の風景が隠さ れることにより，庭が強調されたり奥を感じることによると考えら 
れる。表 6 を見ると, 誘い込まれない理由において, 民家・道路と いった街に関係する空間構成要素があげられているとともに,「外 は少し開けすぎ，見えすぎ」といった理由もあげられている。これ は，本堂から直接街が見えてしまうことから，誘い込まれないとす るものである。

往路については,「本堂一往路」の写真では, 山門は背後に存在 しているため, 写真に直接現れてこない。しかし，山門の見える復 路と同様，はっきりとした違いがある。これは，山門の存在を原因 として境内空間の誘い込み効果が高められている可能性を示して いるのであるが，今後の詳細な研究により解明する必要がある。

\section{5.まとめ}

参詣者を寺院へ誘導するという観点から街と寺院との空間的連 続性を探るため, 参道空間に存在する空間構成要素について誘引評 価実験を行い, 参道空間の誘引効果の状況を把握するとともに, 誘 引効果と空間構成要素との関係性を把握した。

長野県飯山市の 6 寺院について, 参道空間における空間構成要素 （入口・石畳・石段・山門・本堂・橋・折れ曲がり）を往路と復路 とから 2 枚ずつ撮影した写真 51 枚を実験用サンプルとし, 被験者 35 人に対し「非常に誘い込まれる」から「非常に誘い込まれない」 までの 7 段階で誘引評価を評定させ，同時に誘引評価理由を質問す る実験を行った。

(1)主要な誘い込まれる理由は, 往路・復路ともに「先に何があるか 気になるから」であった。

(2)主要な誘い込まれない理由は，往路については「全体像が見えて しまっているから」という終着点の意識, 復路については道路・民 家・電柱といった街に関倸する空間構成要素による理由であった。 (3)入口・石畳・石段・橋の写真では, 往路では誘い込まれる評価と なっていたが復路では誘い込まれない評価となっており，これらの 要素周辺の空間は参道空間において方向性別に顕著に異なる誘引 効果になるよう空間が構成されていることが示された。 (4)入口・石疊・石段・山門の写真の順に，往路において徐々に誘引 評価值が高くなり，復路においても徐々に誘引評価值が低くなって いた。

(5)最も誘引効果が高いと考察できる空間構成要素の写真は山門で あった。

(6)山門有り・山門無し別に本堂の写真の誘引効果を考察することに よって，山門の有無が境内空間の誘い込み効果に対して影響を与え ている可能性が示された。

\section{6. 今後の課題}

被験者の年齢や生活拠点について, 被験者属性別の分析・考察を 行う必要がある。

誘引評価值が急に下がる地点や急に上がる地点といった, 本研究 の結果からみて特異な点に対して考察を深める必要がある。

山門の存在を原因として境内空間の誘い込み効果が高められて いる可能性について, 今後の詳細な研究により解明する必要がある。 空間構成要素の誘引効果が，先をイメージすることによって生じ ているのか, 空間構成要素自体の物理的特徵によるものなのか, 詳
表 5 (山門有り)本堂一復路における誘引評価理由(上位 4 件)

\begin{tabular}{|c|c|c|c|}
\hline 「㧱い远まれる」理由 & 件数 & 「唀い込まれなない理由 & 件数 \\
\hline 庭がきれいだから & 21 & 昊りたくないから & 2 \\
\hline 奥が気になるから & 13 & 様々な要素が混在しすぎているから & 1 \\
\hline 石量によって & 10 & 民家に見えるから & 1 \\
\hline 山門によって & 8 & 目的がないから & 1 \\
\hline
\end{tabular}

表 6 (山門無し)本堂一復路における誘引評価理由(上位 4 件)

\begin{tabular}{|c|c|c|c|}
\hline 「敦い込まれる」理由 & 件数 & 「誘い込まれないり理由 & 件数 \\
\hline 石畳が細長く続いているため & 6 & 民家しかないから & 6 \\
\hline 橋を渡りたいから & 6 & 道路によって & 6 \\
\hline 庭が整っているから & 3 & 先の空間がよくないから & 4 \\
\hline 銅像が気になるから & 2 & 外は少し開けすぎ、見えすぎだから & 4 \\
\hline
\end{tabular}

しく考察する必要がある。

本研究では, 街と寺院との空間的連続性の特徵を考察しようとし たことから，比較的小規模な寺院の参道（全長約 $40 \mathrm{~m} \sim 120 \mathrm{~m}$ ）を対 象としたのであるが, 善光寺のような大規模な寺院の参道（善光寺 の参道全長は約 $400 \mathrm{~m}$ ) についても誘引効果を考察する必要がある。

さらに，本研究で明らかとなった参道空間の誘引効果が街に与え る影響を考察する必要がある。

謝辞

本研究には，修論生であった永原大孝氏に多くの協力を得ていること社103 をここに記して感謝の意を表します。

注

注1）参考文献 1)

注2）参考文献 2)

注3）参考文献 3)

注4）参考文献 4)

注5) 参考文献 5) 12)

注6）参考文献 13) 29)

注7）被験者の属性について, 建築系・非建築系以外にも, 次のような属性が考 えられる。

-1) 被験者の年齢構成:年龄にともなう経験が本研究の実験結果に影響 を与えることは充分考えられる。

-2) 被験者の生活拠点: (1)寺院関係者(実験対象の参道空間を所有, も しくは維持管理している方々)，(2)飯山市住民(飯山で暮らし，日常的に実 験対象の参道空間に接している方々)，(3)飯山市外者(飯山に旅行等で 訪れ，実験対象の参道空間を体験する方々)，といった属性が，本研究の 実験結果に影響を与えることは充分考えられる。

しかしながら, 参道空間の誘引効果という観点での研究は始めたばかり であり，現時点ではデータの蓄樌を優先し実験を進めた。被験者属性別の 分析・考察は, 今後の課題である。

注8）質問 2 に書かれた理由のうち, 質問 1 で”非常に・かなり・やや”誘い込まれ ると評価された場合の理由を誘い込まれる理由, ”非常に・かなり・やや”誘 い込まれないと評価された場合の理由を誘い込まれない理由として集計し た。なお，質問1でどちらでもないと評価された場合の質問 2 に書かれた理 由は，理由の意味から明らかな場合は誘い込まれるむしくは誘い込まれない に集計し，その他は集計からはずした。

注9）図4の誘引評価理由の割合（棒グラフ）は，写真ごとに誘引評価理由を集計 している。例えば「石畳一復路」の誘い込まれる理由については, 表3右側 の「誘い込まれる理由;復路」のうちの「石畳によって(32)」という理由を集計

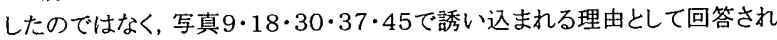
た回答数を集計している。同様に，「誘い込まれない理由」についても，写 真 $9 \cdot 18 \cdot 30 \cdot 37 \cdot 45$ で誘い込まれない理由として回答された回答数を集計 し, 割合を算出している。つまり, 表3右側の「誘い込まれる理由;復路」のう

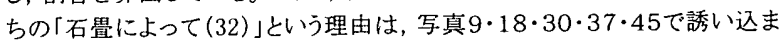
れる理由として回答された場合は図4の誘い込まれる理由に集計されている が，それ以外の写真で回答された場合は図4の誘い込まれる理由には集計 されていない。

注 10) 参考文献 30) 


\section{参考文献}

1）山口満，山崎靖明: 長野県飯山市を事例とした寺町のイメージに関する研 究, 日本建築学会計画系論文集, No.551, pp.213-220, 2002.1

2) カミロ・ジッテ, 大石敏雄訳: 広場の造形, SD 選書 175, 鹿島出版会, 1983.

3）鈴木信弘,志水英樹，山口 満, 杉本正美:アプローチ空間における歩行体 ，験に関する研究，日本建築学会計画系論文集，No.486, pp.51-59,1996.8

4) 船越 徹, 積田 洋, 清水美佐子:参道空間の分節と空間構成要素の分析 (分節点分析・物理量分析) 一参道空間の研究 (その1) - , 日本建築学会計 画系論文報告集, No.384, pp.53-62, 1988.2

5) 船越 徹, 矢島雲居: 参道空間の研究 (その1) 神社の参道の分節と構成要素, 日本建築学会大会学術講演梗概集 (中国), pp.585-586,197.7.10

6) 船越 徹, 矢島雲居, 真利曜子:参道空間の研究 (その2)神社の参道空問の 構成要䒺の分析, 日本建築学会大会学術講演梗概集 (北海道), pp.617-618, 1978.9

7) 船越 徹, 矢島雲居, 真利曜子:参道空間の研究(その3)神社空間における 空間意識の分析 (心理因子分析)，日本建築学会大会学術講演梗概集 (北 海道), pp.619-620,1978.9

8）船越 徹, 積田 洋:街路空間における空間意識の分析(心理量分析)一街 路空間の研究 (その1) - , 日本建築学会論文報告集, No.327, pp.100-107, 1983.5

9）船越 徽, 積田 洋: 街路空間における空間構成要素の分析(物理量分析) 一街路空間の研究 (その2) 一, 日本建筑学会計画系論文報告集, No.364, pp.102-111, 1986.6

10）船越 徹, 積由 洋:街路空間における空間意識と空間構成要素との相関関 係の分析(相関分析) 一街路空間の研究(その3) - , 日本建築学会計画系 論文報告集, No.378,pp.49-57, 1987.8

11）船越 徹:参道空間の演出を読む一分節とシークエンス，建筑・都市計画のた めの空間学, pp.158-173，日本建築学会編，井上畵院，1990.11

12）恒松良純, 船越 徹, 積田 洋:街並みの「ゆらぎ」の物理量分析一街路景観 の「ゆらぎ」に関する研究 (その1)一, 日本建築学会計画系論文集, No. 542 , pp.137-144, 2001.4

13）千葉一輝, 戸沼幸市:近代以降における寺院集積の変容について一東京 の寺院集積地区(寺町)に関する研究 その 1 -, 日本建築学会計画系論文 集, No.491, pp.149-156, 1997.1

14）千葉一輝, 長野吉晴, 戸沼幸市:東京の寺町に関する研究 一その1 寺町 の今日的意義と現状一, 日本建築学会大会学術講演梗概集 (中国), F; pp.7-8, 1990.10

15）長野吉晴，千葉一輝，户沼幸市:東京の寺町に関する研究 一その2 足立 区伊興寺町景観整備計画一，日本建築学会大会学術講演梗概集 (中国) F, pp.9-10, 1990.10

16）松本泰生, 千葉一輝, 戸沼幸市: 東京の寺町に関する研究 - その3 寺院 の移転と寺町の形成についでー, 日本建築学会大会学術講演梗概集 (東 北), F, pp.89-90, 1991.9

17）千葉一輝, 松本泰生, 戸沼幸市: 東京の寺町に関する研究 一その4 寺院 配置のパターンと規模についてー,日本建築学会大会学術講演梗概集 (東 北), F, pp.91-92, 1991.9

18）千葉一輝, 龍治男, 松本泰生, 戸沼幸市:東京の寺町に関する研究 一その 5 上野〜浅草間の寺院集積地区について一, 日本建築学会大会学術講演 梗概集 (北陸), F, pp.511-512, 1992.8

19）龍治男, 千葉一輝, 松本泰生, 戸沼幸市: 東京の寺町に関する研究一その
6 浅草地区の街区空間構造及び整備の方向性一, 日本建築学会大会学術 講演梗概集 (北陸)，F, pp.513-512, 1992.8

20）千葉一輝, 龍治男, 松本泰生, 戸沼幸市: 東京の寺町に関する研究 一その 7 元浅草地区における住民意識一, 日本建築学会大会学術講演梗概集 (関東), F, pp.495-496, 1993.9

21）龍治男，千葉一輝，松本泰生，戸沼幸市:東京の寺町に関する研究 一その 8 上野〜浅草間の寺院 (住職) の意識一, 日本建築学会大会学術講演梗概 集 (関東), F, pp.497-498, 1993.9

22）千葉一輝, 吉田禎雄, 龍治男, 戸沼幸市: 東京の寺町に関する研究 一その 9 東京における寺院墓地の変遷一, 日本建榮学会大会学術講演梗概集(東 海), F, pp.675-676, 1994.9

23）吉田禎雄，千葉一輝，龍治男，戸沼幸市:東京の寺町に関寸る研究 一その 10 東京都心部の寺院特設墓地について一, 日本建築学会大会学術講演 梗概集 (東海)，F, pp.677-678, 1994.9

24）千葉一輝, 大沢信行, 松本泰生, 吉田禎雄, 戸沼幸市:東聰京の寺町に関 寸る研究 一その11 寺院集積地区の都市計画上の扱い一, 日本建築学会 大会学術講演梗概集 (北海道), F, pp.53-54, 1995.8

25）大沢信行, 千葉一輝, 松本泰生, 吉田禎雄, 戸沼幸市: 東京の寺町に関する 研究 一その12 寺院集積地区の領域設定における観点一, 日本建築学会 大会学術講演梗概集 (北海道), F, pp.55-56, 1995:8

26）尾上聰, 佐藤英規, 中内晃次郎, 浅野聡, 佐藤洋一, 平舘亮一, 堀越義章, 高橋正樹, 李宣丕, 戸沼幸市: 足立区伊興寺町に関する調查研究 一その1 伊興町地区の概要及び寺町の使われ方一、日本建築学会大会学術講演梗 概集 (東北), F, pp.1-2, 1991.9

27）中内晃次郎，平舘亮一，佐藤英規，浅野聡，李宣晉，佐藤洋一，堀越義章, 尾上聰, 高橋正樹, 戸沼幸市: 足立区伊興寺町に関する調査研究 -その2 寺町における住民意識一, 日本建築学会大会学術講演梗概集 (東北), F, pp.3-4, 1991.9

28）平舘亮一, 李宣晉, 佐藤洋一, 浅野聡, 尾上鳃, 高橋正樹, 堀越義章, 佐藤 英規, 中内晃次郎, 戸沼幸市: 足立区伊興寺町に関する研究 一その3 寺 院の空間構成一, 日本建築学会大会学術講演梗概集 (東北), F, pp.5-6, 1991.9

29）李宣百, 尾上聰, 高橋正樹, 浅野聡, 佐藤英規, 中内晃次郎, 堀越義章, 佐 藤洋一, 平舘亮一, 戸沼幸市: 足立区伊興寺町に関する研究 一その 4 伊興町地区の空間構成一, 日本建築学会大会学術講演梗概集(東北), F, pp.7-8, 1991.9

30) 永原大孝:参道空間における空間構成要素の誘導効果に関する研究, 2002 年度修士論文, 信州大学大学院工学系研究科社会開発工学専攻, 2003.2

31）伊藤嘉記，山口 満:参道空間における空間構成要素の誘導効果に関する 研究 (その 1 ); 日本建築学会大会学術講演梗概集 (東海)，E-1，985-986, 2003.

32）高山 耕, 山口・満:参道空間における空間構成要素の誘導効果に関する研 究 (その2); 日本建築学会大会学術講演梗概集 (東海)，E-1，987-988， 2003.

(2003年 9 月 10 日原稿受理, 2004 年 5 月 7 日採用決定） 